\title{
Dutch Pendulum Observations in the Atlantic, the Pacific, and the Indian Oceans.
}

$A^{N}$ account of thelfest part of Dr. Vening Meinesz's voyage $p$ nhleard H.M. Submarine K XIII from Helder tor Hpholulu through the Panama Canal was published Jim NATURE of Dec. 25, 1926. I propose now $p$ fixde some particular about the voyages from

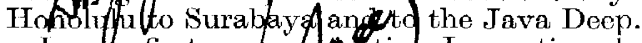

In ny first commatantion I mentioned that the number of obscrqatiogs between Honolulu was 32; there were further:

Manila-Amboina, Nov. 20-Nov. 25.

Amboina-Banda, Nov. 25

Banda-Bima, Dec. 2-Dec. 6

Bima-Surabaya, Dec. 7-Dec, 13

The number of observations at sea during the whole voyage is 113,2 of which were made at the surface of the sea: in the Atlantic, the Philippines, the Straits of Manipa (Moluccas), and the Java Sea. Through a misunderstanding I mentioned in my first communication that the observation in the Atlantic was a failure.

Several observations were made on the same day :

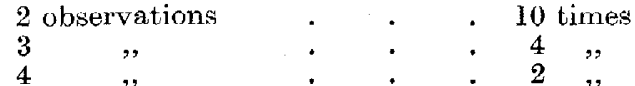

Double observations at sea were made 5 times, 3 of which sailing east and west (Eötvös-effect) and 2 with the freezing apparatus working and idle.

The number of observations in the harbours was 15 ; all were double, with free hanging apparatus and with fastened gimbals.

The time signals used were those of Lembang, Java, given by the radio station of Malabar. Between Honolulu and Manila the signals of Saigon were also audible, and after leuving Manila those of Bordeaux.

Because of the high temperature the films were no longer devoloped on board, but whenevor a harbour was reached development took place. In the long run the quality of the films became less satisiactory; but though the records were not so perfect as might have been, they were still efficient.

The crossing from Honolulu to Guam in nineteen days was exceedingly trying, the temperature of the sea-water being $30^{\circ}$ or $31^{\circ} \mathrm{C}$. Owing to a leakage, tho freezing machine lost all its methyl chloride and remained out of action for the rest of the voyage, as no supply could be made in any of the harbours at which the submarine called.

From Guam so far as the Straits of Surigao the weather was very rough, but happily tho ship was in the rear of the typhoon which had swept over part of the Philippines just before its arrival.

The crew mot a friendly reception at Guam, Yap, and Manila. On the arrival in the Dutch harbours Amboina, Banda, and Bima they were splendidly received by the authoritics and by the population. From Banda the ship did not sail straight to Bima, but in order to make observations it went first in a southern direction so far as the Sahul shoal on the shelf of the Australian continent. In this manner the curved double range of islands on the border of the Banda sea was crossed twice.

On Dec. 13 the ship arrived at Surabaya after a voyage of 200 days, 112 of which had boen sailing days. Tho length of the whole track is 20,600 miles. Never bofore has so long a voyage been performed by an unoscorted submarine. The crew arrived in good health notwithstanding the hardships of so long a stay on board the small vessel, which measured but 800 tons and offered very poor accommodation. The ship and the ongines, built at the yard 'Feyenoord. at
Rottordam, were during the whole voyage in the most perfect condition.

Vice-Admiral A. F. Goossens, Commander of the Fleet and Chief of the Navy Department at Batavia, was prosent to welcome the crew, and informed Commander van der Kun and Dr. Vening Meinesz that H.M. the Queen had been pleased to make both of them officers in the Order of Oranjo-Nassau, whilst many among the officers and the crew received other marks of distinction. The first days at Surabaya brought a series of festivities.

After having made one more observation in the harbour of Surabaya, Dr. Vening Meinesz was able to go to tho mountains for a well-deserved rest. But again and again this rest was interrupted by his giving lectures in the principal towns of Java about his voyage.

On meeting the admiral at Surabaya, Dr. Vening Meinesz had availed hirnself of the opportunity to request if before his return to Holland H.M. Submarine $\mathrm{K}$ XIII could once more be placed at his disposal for the making of pendulurn observations in the deep south of Java. This request was granted diroctly; so, on Feb. 3 he again embarked at Surabaya and sailed through the Straits of Bali into the Indian Ocean. The observations were made in four profiles perpendicular to the Java Deep ; they are twenty-six in number, and will give a complete record of the gravity in this part of the ocean. The results have not yet been computed.

The submarine sailed through the Straits of Sunda to Batavia, where Dr. Vening Meinesz disembarked on Feb. 14. He left Java on Mar. 9 on board a mail steamer, and arrived at Amsterdam on April 9. At the meeting of the Amsterdam Acadomy of Sciences on June 25 he read a paper upon the provisional results of his observations and the conclusions which, with some reservation, may be drawn from them. 'These conclusions are principally the following :

1. In the $A$ tlantic and the l'acific there are excesses of gravity extending over large areas. As has been explained by Dr. W. Bowie and C. H. Swick, both of the U.S. Coast and Geodetic Survey, these may bo caused partially by a depression of the geoid with regard to the spheroid. The final computations will show in how far this circumstance may account for the excesses.

2. It is unlikely that the longitude torms introduced by Helmert and by TTeiskanen in the formulæ will agree with the values of gravity obtained in the oceans.

3. Tn the Pacific there exists a remarkable parallelism between the variations of the anomalies and of the sea-depths.

4. The observations made above the four deeps all show a romarkable defect of gravity in the middle of the doep. The excesses on the borders do not make the impression that they may be aseribed to an excess of mass below the deops, required for isustatic compensation, but give rise to the supposition of tangential pressuro in the earth's crust.

6. The observations at the feet of the continental slopes give greater values of the gravity than should be the case according to the current theory.

6. The results obtained in the Banda Sea, especially near tho doublo range of islands, show a large excess at tho inside; that gradually changes into a very noticeable defect at the outside, where the tangential pressures which are probable in this part of the archipelago should make an excess probable. The great anomalies are in accordance with the general view that in this part of the world the earth-crust was recontly, or is still at present, in a labile condition.

No. 3033, VoL. 120] 
7. In general, the results obtained at sea give the impression of greater regularity than those obtained on land. This agrees with what was expected. The outer layer of water immediately below the observer is homogeneous and the disturbing masses in the solid crust are farther away. Moreover, the deformation caused by erosion is absent.

The list of the provisional results of Dr. Vening Meinesz's observations in the Atlantic and the Pacific is published in the Proceedings of the Amsterdam Academy of Sciences. The complete definite results, together with the isostatic reductions computed by the courtesy of the U.S. Coast and Geodetic Survey, will be published by the Dutch Geodetic Committee in the course of 1928 .

Thanks to the skill of Dr. Vening Meinesz, the problem of the determination of gravity at sea is solved. By his indefatigable effort and the splendid co-operation of the Royal Dutch Navy, the earth is now surrounded by a chain of gravity observations, which will procure the necessary data for a crucial test of the existing theories about the constitution of the earth's crust. Dr. Vening Meinesz has been appointed professor of geodesy at the University of Utrecht, and is now a member of the Dutch Geodetic Committee.
J. J. A. Muller.

\section{Forestry in Kenya Colony.}

$\mathrm{T}^{\mathrm{H}}$

EE Forestry Department in Kenya has been in existence for more than a quartor of a century, the Forestry Ordinance dafing 1911 . In the annual report for the year fod $D e$. 31, 1926, it is claimed that the far 4 on dealt with was "a notable one, and in many desle to the most successful in the history of the Department." For the first time, it is said, the revenue was in excess of the expenditure. The revenue of $£ 36,938$ exceeded the expenditure by $\mathfrak{£ 7 0 8 3}$ and was 45 per cent. larger than that of any previous year. The Acting Conservator rightly remarks that a record exploitation of the forests would not necessarily imply a successful year. It might mean, he adds, as it has in many countries, record forest destruction and diminution of the capital forest wealth. Unfortunately, such destruction is still in force in different parts of the world. But it may be asked, is Kenya herself on sure ground in this respect? It is true the Acting Conservator points out that the record exploitation in Kenya in 1926 was accompanied by record progress in afforestation and re-afforestation, "the area of 3047 acres planted during the year being more than sufficient to replace the forest cüt during the year." It is not apparent, however, from the report, on what premises such a statement rests.

One of the most serious features of the present position of the Department and its forests is to be found in the fact that no trustworthy estimate of the quantities of timber in the forests exists; in other words, no enumeration of the growing stock as a whole in the forests under the Department has yet been made. This the report quite rightly states is "the most unsatisfactory aspect of the forestry position."

The exploitation work is carried out by sawmill companies, which are granted timber-felling licences. Twenty-three of these firms worked in the forest reserves during the year, the area subject to such exploitation being approximately 447,518 acres, though it is estimated that not more than 197,700 acres of this area carried marketable timber. "As the rate of cutting," says the report, "varies very greatly with the different licence-holders, the total area under licence is no guide to the rate of exploitation of the Colony's forests. The only sure critorion by which to judge the Colony's forest position is a comparison of the annual cut with a reliable estimate of the total stock of mature timber in the forests. There is at present no such estimate available, nor can one be obtained without a considerable increase of the present. Staff of the Department."

The plain meaning of these statements is that the forests are being worked without an adequate knowledge of their contents or what is the annual possibility. It should not prove difficult to settle this important matter, if only roughly, in order to avoid the grave chance of overcutting. It is fairly common knowledge how Brandis, single-handed, tackled a like proposition in Pegu in Burma in 1856. The Department in Kenya is obviously understaffed. But at least there is a trained officer in charge of each forest district. It can surely not be held that there is any work, however apparently important, not even planting work, which should take precedence over the carrying out of enumeration surveys, however rough, of the growing stock of the forests. For the exploitation work being conducted and the revenue accruing thereby is only justified, in economic forestry, when based on some adequate knowledge of the volume of growing stock per unit of area standing in the forests. Such knowledge, the Acting Conservator states, is non-existent. In its absence, fellings, according to modern forest practice and precept, should be made as sparingly as possible.

The other point in the report is the assertion that the planting work undertaken during the year, amounting to 3047 acres, is more than sufficient to replace the forest cut over during the same period. The volumes obtained from the latter were $1,316,566 \mathrm{cub}$. ft. of timber and $5,207,403 \mathrm{cub}$. ft. of firewood. An analysis of the planting work shows that 1195 acres were planted as fuel plantations for the supply of firewood to the railway. This area has no reference, therefore, to future timber production. The planting work to replace the timber felling comprised 860 acres of pencil cedar, 276 acres of other indigenous timber species, and 274 exotic timber species, or an area of 1410 acres in all. The balance of 442 acres was mangroves. Though admittedly a considerable portion of this planting work is still in the experimental stage, yet considerable success is being attained. Nevertheless, it appears somewhat optimistic, with the known history of the costly failures which have been experienced elsewhere in the past, to claim that this planting work will suffice to replace the forest areas cut during the year.

The report points to the necessity of undertaking research work in connexion with the forests and the need of special research officers. The beginnings of such research work have been initiated by the staff, and some very creditable work has already been achieved. Work of this nature, however, must be carried on with continuity, and the latter is not possible in the absence of the whole-time worker. But the mere enumeration of the growing stock of the Kenya Forests does not fall within the province of 'research.' It might be suggested that the best solution of this research question, as in the long run of the staff and its future prospects, would be the amalgamation of the gazetted forest staffs of the four colonies, Kenya, Uganda, Tanganyika, and Nyasaland, on to one list; following the precedent forced upon India some years after the Forest Service there was inaugurated.

In conclusion, it should be said that this report is a most interesting document and beautifully got up by the Government Press, Nairobi. In this latter respect it forms a model which some other Colonial government presses might take as a guide.

No. 3033, VoL. 120] 